\title{
Mangrove (Rhizophora sp) Fruit Extract Inhibits Tumor Growth Factor (TGF)-ß1 Expression in High Cholesterol Diet-Fed Rats
}

\section{(Ekstrak Buah Bakau (Rhizophora sp) Menghambat Ekspresi Tumor Growth Factor(TGF)-ß1 pada Tikus yang Mendapat Diet Tinggi Kolesterol)}

\author{
Muhammad Yulis Hamidy ${ }^{*}$, Huriatul Masdar², Winarto ${ }^{2}$ \\ I*Department of Pharmacology, Faculty of Medicine, Universitas Riau, Pekanbaru, Indonesia \\ ${ }^{2}$ Department of Histology, Faculty of Medicine, Universitas Riau, Pekanbaru, Indonesia \\ *E-mail: yulis.hamidy@gmail.com
}

Article Info:

Received: 8 October 2021

in revised form: 20 November 2021

Accepted: 30 November 2021

Available Online: 1 December 2021

Keywords:

Mangrove

Rhizophora sp

TGF- $\beta 1$

Atherosclerosis

Corresponding Author:

Muhammad Yulis Hamidy

KJFD Farmakologi

Fakultas Kedokteran

Universitas Riau

Pekanbaru

28111

Indonesia

email: yulis.hamidy@gmail.com

\begin{abstract}
Background: Atherosclerosis is a major finding in cardiovascular disease. One of the pro-fibrotic cytokines that play an important role in the atherosclerosis process is Tumor Growth Factor (TGF)- $\beta 1$, where the presence of high TGF- $\beta 1$ secretion due to hypercholesterolemia will trigger excessive collagen matrix formation. Objective: To analyze Rhizophora $s p$ fruit extract effect on TGF- $\beta 1$ expression in high cholesterol diet-fed rats. Material and Methods: Eighteen 10-week-old rats weighing 150-200 g were used in this study. These animals were grouped into 3 groups, each consisting of 6 rats. Group A (normal control) is a group of rats that received a normal diet. Group B (atherogenic control) received a diet that induces atherosclerosis (atherogenic diet). This diet contains 2\% cholesterol, 5\% goat fat, $0.2 \%$ cholic acid and standard diet up to $100 \%$. Atherogenic diet was given for 3 days, and on the first day this group also received vitamin D3 700,000 IU/kg. Group C (treated), besides receiving an atherogenic diet, was also given Rhizophora $s p$ fruit extract $500 \mathrm{mg} / \mathrm{kg}$ body weight. The Rhizophora $s p$ fruit extract effect on TGF- $\beta 1$ expression was evaluated by immunohistochemical procedure. The area of the expression is calculated using the ImageJ software. Results: The results indicated that the expression of TGF- $\beta 1$ is higher in the group receiving the atherogenic diet than the normal control group (17.3 vs. 8.9; $P=0.000)$. Rhizophora $s p$ fruit extract reduced the expression remarkably (17.3 vs. $11.4 ; P=0.001)$. Conclusion: Rhizophora sp fruit extract inhibits the expression of TGF- $\beta 1$ in high cholesterol diet-fed rats.
\end{abstract}

How to cite (APA $6^{\text {th }}$ Style):

Hamidy, M. Y., Masdar, H., Winarto. (2021). Mangrove (Rhizophora sp) Fruit Extract Inhibits Tumor Growth Factor (TGF)$\beta 1$ Expression in High Cholesterol Diet-Fed Rats. Jurnal Farmasi Galenika :Galenika Journal of Pharmacy (e-Journal), 7(3), 213-220. doi:10.22487/j24428744.2021.v7.i3. 15667. 


\begin{abstract}
ABSTRAK
Latar Belakang: Aterosklerosis merupakan kelainan utama yang ditemukan pada penyakit kardiovaskular. Salah satu sitokin profibrotik yang berperan penting dalam proses aterosklerosis adalah Tumor Growth Factor (TGF)- $\beta 1$, dimana adanya sekresi TGF- $\beta 1$ yang tinggi akibat hiperkolesterolemia akan memicu pembentukan matriks kolagen yang berlebihan. Tujuan: Menganalisis pengaruh ekstrak buah Rhizophora sp terhadap ekspresi TGF- $\beta 1$ pada tikus yang diberi diet tinggi kolesterol. Bahan dan Metode: Delapan belas ekor tikus berumur 10 minggu dengan berat badan 150-200 g digunakan dalam penelitian ini. Tikus dikelompokkan menjadi 3 kelompok yang masing-masing terdiri dari 6 ekor tikus. Kelompok A (kontrol normal) adalah kelompok tikus yang mendapat diet normal. Kelompok B (kontrol aterogenik) diberi diet yang menginduksi aterosklerosis (diet aterogenik). Diet aterogenik ini mengandung kolesterol 2\%, lemak kambing 5\%, asam kolat 0,2\% dan diet standar hingga 100\%. Diet aterogenik diberikan selama 3 hari, dan pada hari pertama kelompok ini juga mendapat vitamin D3 $700.000 \mathrm{IU} / \mathrm{kg}$. Kelompok C (perlakuan), selain diberi diet aterogenik, juga diberikan ekstrak buah Rhizophora sp $500 \mathrm{mg} / \mathrm{kg}$ BB. Efek ekstrak buah Rhizophora sp terhadap ekspresi TGF- $\beta 1$ dievaluasi dengan prosedur imunohistokimia. Area ekspresi dihitung menggunakan software ImageJ. Hasil: Hasil penelitian menunjukkan bahwa ekspresi TGF- $\beta 1$ lebih tinggi pada kelompok yang mendapat diet aterogenik dibandingkan kelompok kontrol normal $(17,3$ vs 8,$9 ; P=0,000)$. Pemberian ekstrak buah Rhizophora sp menghambat ekspresi ini (17,3 vs 11,4; $P=0,001)$. Kesimpulan: Ekstrak buah Rhizophora sp menghambat ekspresi TGF- $\beta 1$ pada tikus yang diberi diet kolesterol tinggi.
\end{abstract}

Kata kunci: Mangrove, Rhizophora sp, TGF- $\beta 1$, Aterosklerosis.

\title{
INTRODUCTION
}

Atherosclerosis is the most common underlying cause of cardiovascular disease. Approximately $30 \%$ of deaths in the world are caused by this cardiovascular disease (WHO, 2009). The pathomechanism of atherosclerosis involves various processes including endothelial dysfunction, inflammatory reactions, cellular proliferation, matrix alteration and thrombosis (Hermann et al, 2010). Inflammatory reactions that occur in atherosclerosis can be mediated by Low Density Lipoprotein (LDL) or oxidized LDL (ox-LDL). This ox-LDL causes endothelial dysfunction, infiltrates the vascular tunica muscularis and triggers the secretion of growth factors such as Tumor Growth Factor (TGF)- $\beta$, causing vascular hypercellularity and proliferation of extracellular fibrocollagen matrix (Aronson, 2003).

One of the efforts to reduce mortality due to atherosclerosis is through the development of phytopharmaceuticals by utilizing existing natural resources. Exogenous antioxidants derived from various plants can be used to prevent oxidative stress so that its effects at the cellular level can be prevented. Mangroves are plants that are quite commonly found in the coastal areas of Riau. Rhizophora sp is a type of mangrove that is quite easy to find in various mangrove forests in Riau (Bakar et al, 2013).

Various studies have proven the potential effect of mangroves as antibacterial (Abeysinghee, 2010; Sahoo et al, 2012), anti-inflammatory, antitumor (Prabhu and Guruvayoorappan, 2012), and antidiabetic (Gurudeeban et al, 2012) due to the presence of active compound such as flavonoids, saponins, tannins, sterols, polyphenols, and alkaloids contained in both the stems, leaves and fruit of 
mangroves. Our previous research has shown the potential effect of Rhizophora sp in inhibiting the process of atherosclerosis where the administration of Rhizophora sp mangrove fruit extract was able to suppress the process of foam cell formation at the early stage of atherosclerosis (Hamidy et al, 2020).

This research aimed to analyze the effect of Rhizophora sp fruit extract on the expression of TGF- $\beta 1$ which is the initial process of fibrosis in atherosclerosis in rats induced by a high cholesterol diet (atherogenic diet).

\section{MATERIAL AND METHODS}

\section{Mangrove (Rhizophora sp) fruit extract}

This study used mangrove (Rhizophora sp) fruits originating from Meranti District, Province of Riau, Indonesia. Prior to use, identification of this plant was carried out. The identification process is carried out at the Faculty of Agriculture, University of Riau. Furthermore, the mangrove fruit is washed thoroughly, then cut into thin strips and then dried for a week in an open space. After drying, the mangrove fruit strips were mashed to flour. The flour was then dissolved in ethanol in a ratio of 1:7 (weight/volume) and stored for one day using a Soxhlet Apparatus. The extract formed was then evaporated using a rotary evaporator at a temperature of $50^{\circ} \mathrm{C}$. The resulting flour was stored at $4{ }^{\circ} \mathrm{C}$ and ready to be tested.

\section{Experimental animals}

The animals used in this study were male Wistar rats aged 10 weeks and weighing 150-200 g. The rats were obtained from the School of Pharmacy, University of Riau. All animals were in good health. Rats were kept in comfortable cages and given food and drink as needed. The rats were placed in a room that had adequate ventilation and lighting at a temperature $20-26^{\circ} \mathrm{C}$. Experimental animals underwent acclimatization for one week before the treatment was given. During the acclimatization process the rats' health was monitored continuously. The used of experimental animals in this study was subjected to the declaration of Helsinki. This study has received ethical approval from the Ethical Committee for Medicine \& Health Research, Medical Faculty, University of Riau with the number No:099/UN.19.5.1.1.8/UEPKK/2019.

\section{Experimental design}

Experimental animals were divided into three experimental groups $(n=6)$, Group A was a normal control group got a standard diet. Group B (atherogenic control) received a diet that induces atherosclerosis (atherogenic diet). This diet contains $2 \%$ cholesterol, $5 \%$ goat fat, $0.2 \%$ cholic acid (Sigma, St. Louis, MO, USA) and standard diet up to $100 \%$. Atherogenic diet was given for 3 days, 
and on the first day this group also received vitamin D3 (cholecalciferol) 700,000 IU/kg (Sigma, St. Louis, MO, USA). Administration of an atherogenic diet aimed to induce the initiation of atherosclerosis in rats (Ismawati et al, 2016). Group C got a high cholesterol diet along with Rhizophora sp fruit extract $500 \mathrm{mg} / \mathrm{kg}$ given orally using a gastric tube once a day.

\section{Immunohistochemical staining}

The rats were sacrificed at the end of the treatment using ether anesthesia. The rat aorta was identified and excised rapidly. The aorta was then fixed in $10 \%$ neutralized formaldehyde in $0.1 \mathrm{M}$ phosphate buffer. Furthermore, the rats aortic tissue was made into a paraffin block. Anti-TGF $\beta 1$ (SigmaAldrich, St. Louis, MO, USA) was used to identify TGF- $\beta 1$ in rat aorta. TGF- $\beta 1$ expression appears as brown color on immunohistochemical staining. Expression measurements were performed by measuring the proportion of brown stained areas using the ImageJ program (Image J 1.49v software, National Institute of Health, Bethesda, MD, USA). Areas colored positively are reported in percent. Area measurement was carried out by taking photomicrographs at 1000x magnification (objective $40 \mathrm{x})$ in 5 different areas of the tunica media.

\section{Statistical analysis}

The data obtained were presented as mean \pm SD and were analyzed by one-way ANOVA followed by Bonferroni's post hoc test. Statistically significant was considered when $P<0.05$.

\section{RESULTS AND DISCUSSION}

The effect of Rhizophora sp fruit extract on TGF- $\beta 1$ expression was assessed by immunohistochemical examination. Immunohistochemical illustration of TGF- $\beta 1$ expression in the three groups can be seen in Figure 1 below.

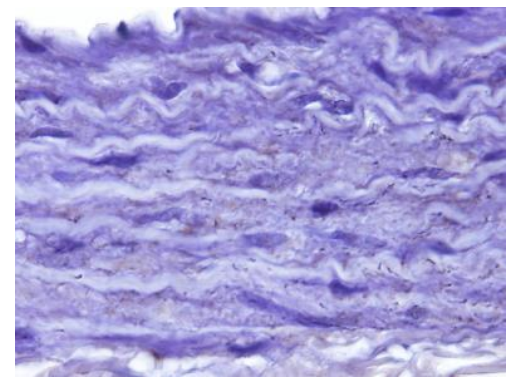

A

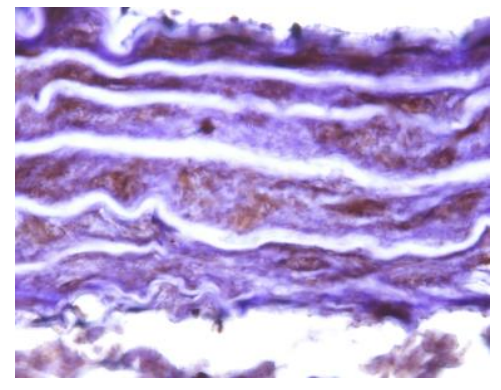

B

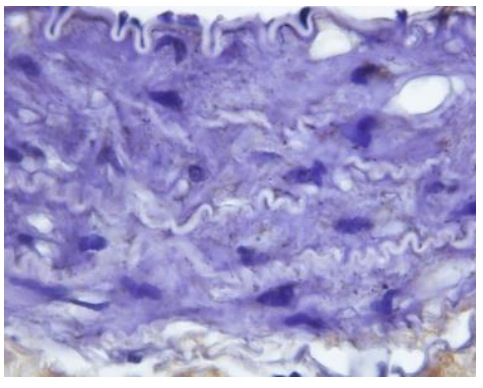

$\mathrm{C}$

Figure 1. Immunohistochemical illustration of TGF- $\beta 1$ expression in rats aorta
A. Normal diet
B. Atherogenic diet
C. Atherogenic diet + Rhizophora sp. fruit extract 
Furthermore, TGF- $\beta 1$ expression in rats aorta was assessed using the ImageJ program as shown in Figure 2 below.

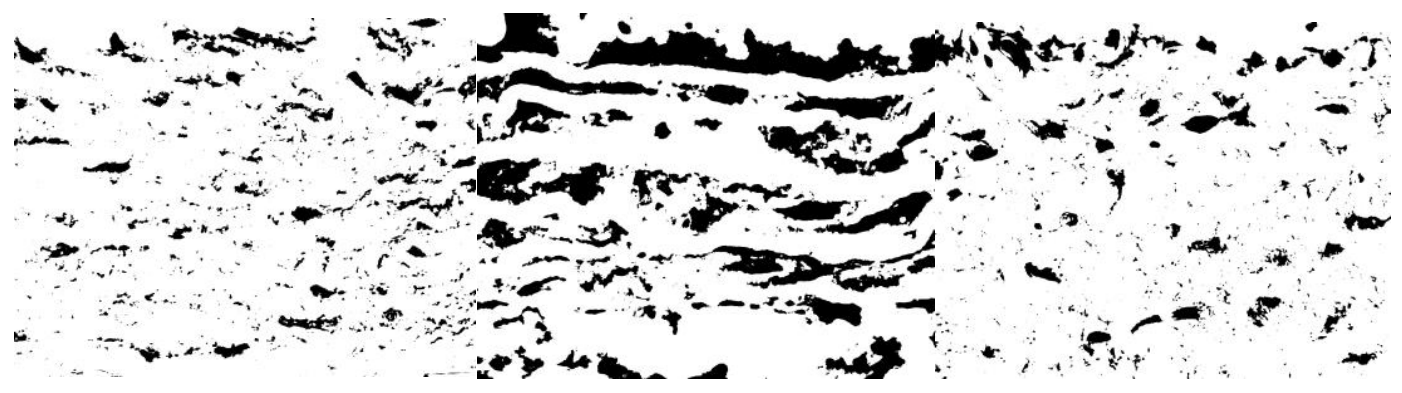

A

B

$\mathrm{C}$

Figure 2. Measurement of TGF- $\beta 1$ expression in the rats aorta using the imageJ program

A. Normal diet

B. Atherogenic diet

C. Atherogenic diet + Rhizophora sp. fruit extract

Examination area of the tunica media; objectives 100x; d scale $100 \mu \mathrm{m}$; $\mathrm{h}$ scale $10 \mu \mathrm{m}$.

The results of measurement of TGF- $\beta 1$ expression in each group can be seen in Table 1 below.

Table 1. The expression of TGF- $\beta 1$ among experimental groups.

\begin{tabular}{lcc}
\hline \multicolumn{1}{c}{ Experimental groups } & TGF- $\beta 1$ expression (\%) & $\mathrm{P}$ \\
\hline Normal diet & $8.91 \pm 0.84$ & \\
Atherogenic diet & $17.33 \pm 4.22$ & $\mathrm{p}=0.000$ \\
Atherogenic diet + Rhizophora sp. fruit extract & $11.45 \pm 1.13$ & \\
\hline
\end{tabular}

Values are presented as mean $\pm \mathrm{SD}(\mathrm{N}=6)$.

Based on the statistical analysis using ANOVA, there were significant differences between the eperimental groups and continued with the post hoc test as shown in Table 2 below.

Table 2. Post hoc test results of TGF- $\beta 1$ expression between groups.

\begin{tabular}{lc}
\hline \multicolumn{1}{c}{ Comparison between groups } & $\mathrm{P}$ \\
\hline Normal diet v Atherogenic diet & $\mathrm{p}=0.000$ \\
Normal diet v Atherogenic diet + Rhizophora sp. fruit extract & $\mathrm{p}=0.012$ \\
Atherogenic diet v Atherogenic diet + Rhizophora sp. fruit extract & $\mathrm{p}=0.001$ \\
\hline
\end{tabular}

The data were statistical analyze using one-way ANOVA followed by Bonferroni's test on SPSS 17.0.

This study showed that the group that received the normal diet showed weak expression of TGF- $\beta 1$ in the intracellular tunica media and in the extracellular matrix. TGF- $\beta 1$ is also expressed in adventitia and peri-aortic connective tissue. In the group that received a high-cholesterol diet, there was an increase in TGF- $\beta 1$ expression in the tunica media which was higher than the group that received a 
normal diet. The group that received the Rhizophora sp fruit extract showed a weaker expression of TGF- $\beta 1$ than the group that received a high-cholesterol diet.

TGF- $\beta 1$ is a profibrogenic cytokine that can be stimulated locally, one of which is in hypercholesterolemic states. The presence of TGF- $\beta 1$ expression can trigger fibrocollagen matrix synthesis and cell proliferation. The higher the amount of TGF- $\beta 1$ that is expressed will cause more fibrocollagen matrix to be synthesized, without being offset by the degradation of the matrix, which can lead to vascular fibrosis ( $\mathrm{Li}$ et al, 2004).

This study showed that mangrove (Rhizophora $\mathrm{sp}$ ) fruit extract inhibits TGF- $\beta 1$ expression in aorta of rats induced by an atherogenic diet. Mangrove is a halophyte plant that can withstand in high salt conditions and can grow in low oxygen environments. Mangroves grow abundantly in Indonesia where around 47 species of mangroves are found in this country, such as family Rhizophoraceae, Sonneratiaceae, Avicenniaceae and Meliaceae. Previous study has shown both the stems, leaves and fruit of Rhizophora sp has benefits not only as an antimicrobial and anticancer, but also as an antioxidant. This plant contains phenols, flavonoids, butanol, and methanol which play a role in the scavenging activity of free radicals (Bakar et al, 2013).

The high cholesterol diet was used to induce hypercholesterolemia in experimental rats (Harsha et al, 2018). Hypercholesterolemia causes LDL to infiltrate blood vessels, particularly at the area with hemodynamic disruption. LDL converted to ox-LDL by oxidative and enzymatic modifications (Hansson, 2005). The immune response is a predominant process in the pathogenesis of atherosclerosis which is mediated by ox-LDL (Ross, 1999). oxLDL can induce endothelial dysfunction, infiltrate mesangial and blood vessels, and further induce the secretion of growth factors such as Tumor Growth Factor $\beta$ (TGF- $\beta$ ) which causes vascular hypercellularity and proliferation of the extracellular matrix (Horkko et al, 2000).

Based on previous research, it is known that mangroves contain several active ingredients that have antioxidant effects. This antioxidant effect is produced by inhibiting stress signaling pathways such as NF- $\kappa$ B, MAPK and JAK-STAT pathways. Inhibition of this pathway will further suppress the activity of free radicals so that they can inhibit the formation of superoxide. If superoxide is not formed, cellular oxidative stress can be prevented (Das et al, 2016). This may explain the protective effect shown by the fruit extract of Rhizophora sp in inhibiting TGF- $\beta 1$ expression in this study.

\section{CONCLUSION}

As the conclusion, the present study suggested mangrove (Rhizophora $\mathrm{sp}$ ) fruit extract has pharmacological effects by inhibiting TGF- $\beta 1$ expression. The results obtained in this study provide opportunities for potential use of mangrove (Rhizophora $\mathrm{sp}$ ) in the future. 


\section{ACKNOWLEDGEMENT}

The authors would like to thank the University of Riau which has funded this research.

\section{CONFLICT OF INTEREST}

No conflict of interest.

\section{REFERENCES}

Abeysinghe, P. D. (2010). Antibacterial activity of some medicinal mangrove against antibiotic resistant pathogenic bacteria. India J Pharm Sci, 72(2), 167-72.

Aronson, D. (2003). Cross-linking of glycated collagen in the pathogenesis of arterial and myocardial stiffening of aging and diabetes. J Hypertens, 21(1), 3-12.

Bakar, A., Purnama, P., Rahmayuni, R. (2013). Pengelolaan hutan mangrove dan pemanfaatannya dalam meningkatkan ekonomi masyarakat pesisir pantai Provinsi Riau. Kutubkhanah, 16(2), 94-103.

Das, S. K., Samantaray, D., Patra, J. K., Samanta, L., Thatoi, H. (2016). Antidiabetic potential of mangrove plants: a review. Frontiers in Life Sci, 9(1), 75-88.

Gurudeeban, S., Satyavani, K., Ramanathan, T., Balasubramanian, T. (2012). Antidiabetic effect of a black mangrove species Aegiceras corniculatum in alloxan-induced diabetic rats. J Adv Pharm Technol Res, 3(1), 52-6.

Hamidy, M. Y., Masdar, H., Darmawi, D. (2020). Effect of Mangrove (Rhizophora sp) Fruit Extract on Foam Cell Formation at the Initiation Stage of Atherosclerosis. Biomed Pharmacol J, 13(1).

Hansson, G. K. (2005). Inflammation, atherosclerosis, and coronary artery disease. N Engl J Med, $352,1685-95$.

Harsha, S., Ankita, J., Harsha, L., Deepak, B.(2018). Anti-oxidative, anti-inflammatory and antiatherosclerotic effect of taurine on hypercholesterolemia induce atherosclerotic rats. Int $\mathbf{J}$ Pharm Pharm Sci, 10(3), 145-150.

Herrmann, J., Lerman, L. O., Lerman, A. (2010). On to the road to degradation: atherosclerosis and the proteasome. Cardiovasc Res, 85, 291-302.

Horkko, S., Binder, C. J., Shaw, P. X., Chang, M. K., Silverman, G., Palinski, W., Witztum, J. L. (2000). Immunological responses to oxidized LDL. Free Radic Biol Med, 28, 1771-9.

Ismawati, Oenzil, F., Yanwirasti, Yerizel, E. (2016). Changes in expression of proteasome in rats at different stages of atherosclerosis. Anat Cell Biol, 49, 99-106.

Krishnamoorthy, M., Sasikumar, J. M., Shamna, R., Pandiarajan, C., Sofia, P., Nagarajan, B. (2011). Antioxidant activities of bark extract from mangroves, Bruguiera cylindrica (L.) Blume and Ceriops decandra Perr. Indian J Pharmacol, 43(5), 557-62.

Li, W. Q., Qureshi, H. Y., Liacini, A., Dehnade, F., Zafarullah, M. (2004). Transforming growth factor beta induction of tissue inhibitor of metaloproteinase 3 in articular chondrocytes is mediated by reactive oxygen species. Free Radic Biol Med, 37, 196-207. 
Prabhu, V. V., Guruvayoorappan, C. (2012). Anti-inflammatory and anti tumor activity of the marine mangrove Rhizophora apiculata. J Immunotoxicol, 9(4), 341-52.

Ross, R. (1999). Atherosclerosis: an inflammatory disease. N Engl J Med, 340,:115-126.

Sahoo, G., Mulla, N. S. S., Ansari, Z. A., Mohandes, C. (2012). Antibacterial activity of mangrove leaf extracts against human pathogens. Indian J Pharm Sci, 74(4), 348-51.

World Health Organization. (2009). Cardiovascular diseases fact sheet. Geneva: World Health Organization. 